\title{
Pola Materi Kebahasaan, Monitoring, dan Evaluasi Pembelajaran Bahasa pada Buku Tematik Sekolah Dasar Kelas 1
}

\author{
Yenny Puspitawati ${ }^{1}$, Markhamah ${ }^{2}$ \\ ${ }^{1,2}$ Universitas Muhammadiyah Surakarta, Indonesia
}

DOI: 10.23917/humaniora.v22i2.11388

Submit: 4 Juli 2020. Revisi: 13 April 2021. Diterima: 18 Juni 2021

Available Online: 7 Juli 2021. Periode Terbit: Agustus 2021

\begin{tabular}{l}
\hline Kata Kunci \\
\hline elementary school, \\
language learning, \\
monitoring, \\
evaluation \\
\\
\hline Corresponding Author \\
\hline Yenny Puspitawati \\
Universitas Muhammadiyah \\
Surakarta \\
Indonesia \\
Email: \\
yennypuspitawati24@gmail.com \\
Telp: -
\end{tabular}

\section{Abstrak}

This research has two aims. 1) to describe the pattern of language learning in primary school thematic text-books used in grade 1; and 2) to describe how to monitor and evaluate language learning in school thematic text-books used in the basic class in grade 1. By using the method of listening and tapping as well as note-taking techniques, we collected our data sourced from the 2013 thematic integrated curriculum book for elementary school students grade one. The data that have been obtained are then analyzed and presented formally in the narrative form. The results of this study indicate that of the 8 themes that are represented in the 8 books are able to present aspects and language competencies that are rather systematic. In addition, the training and evaluation monitoring sheet in the form of "Now I Can" can make it easier for teachers to measure the achievement and success of each student's learning comprehensively and validly.

\begin{tabular}{ll}
\hline Kata Kunci & Abstrak \\
\hline sekolah dasar, & Penelitian ini memiliki dua buah tujuan: 1) mendeskripsikan \\
pembelajaran bahasa, & pola pembelajaran bahasa pada buku tematik sekolah dasar \\
monitoring, & kelas I; 2) mendeskripsikan monitoring dan evaluasi pembelaja- \\
evaluasi & ran bahasa pada buku tematik sekolah dasar kelas I. Dengan \\
& menerapkan metode simak dan teknik sadap dan catat, penulis \\
& mengumpulkan data yang bersumber dari Buku Tematik \\
& Terpadu Kurikulum 2013 Buku Siswa SD/MI Kelas I. Data \\
& yang sudah diperoleh kemudian dianalisis dan disajikan secara \\
& formal dalam bentuk narasi. Hasil penelitian ini menunjukkan \\
& bahwa dari 8 tema yang terdapat pada 8 buku tersebut, dapat \\
& diperoleh aspek serta kompetensi bahasa yang cukup sistematis. \\
& Selain itu, adanya lembar monitoring latihan dan evaluasi yang \\
berupa "Sekarang Aku Bisa" dapat memudahkan guru untuk \\
mengukur ketercapaian dan keberhasilan pembelajaran dari \\
masing-masing siswa secara komprehensif dan nyata.
\end{tabular}

\section{PENDAHULUAN}

Perkembangan usia anak, dalam hal ini peserta didik pada tingkat sekolah dasar, merupakan masa perkembangan dan pertumbuhan yang memerlukan perhatian lebih. Di usia sekolah dasar khususnya usia kelas 1, anak cenderung melihat sesuatu secara holistik. Oleh karena itu, orang tua dan guru perlu memperhatikan dengan cermat pola asuh, pola belajar serta lingkungan sekitar 
agar potensi yang dimiliki oleh anak dapat berkembang dengan optimal. Pembentukan potensi, pola pikir dan karakter tidak bisa dilakukan secara sertamerta. Orang tua bertanggung jawab penuh terhadap perkembangan serta pertumbuhan anak. Sukmadinata (2009) membagi perkembangan kepribadian anak dari berbagai aspek, yaitu aspek fisik dan motorik, aspek intelektual, aspek sosial, aspek bahasa, aspek emosi, serta aspek moral dan keagamaan. Aspek bahasa menjadi salah satu indikator dalam perkembangan anak. Sejak usia 0 bulan, anak sudah mempelajari bahasa dengan cara mendengar kata-kata yang dikeluarkan oleh orang sekitar. Sesuai dengan pertambahan usia, terdapat perkembangan aspek kebahasaan, mulai dari mendengar, mengeluarkan bunyi, melafakkan kata, kalimat, serta unsur kebahasaan lain. Mempelajari bahasa pada anak merupakan gerbang utama untuk mempelajari ilmu-ilmu yang lain. Karena dalam kerangka berfikir manusia, bahasa merupakan alat untuk membantu menyampaikan serta memahami ilmu. Oleh karena itu, hal ini menjadi penting bagi setiap anak untuk mempelajari bahasa supaya keilmuannya dapat berkembang dengan optimal.

Saat memasuki usia sekolah dasar, anak akan belajar secara formal di sekolah. Di tahap ini, terdapat peran guru yang juga memiliki andil dalam perkembangan anak. Guru tidak hanya memberikan pelajaran atau pengetahuan, tetapi juga transformasi serta internalisasi nilai-nilai sehingga dapat membentuk potensi, pola pikir, dan karakter anak dengan baik. Pelajaran yang diberikan pada pembelajaran formal di sekolah disesuaikan dengan tingkat satuan pendidikan. Penyusunan materi ajar pada sekolah dasar yang sesuai dengan kurikulum 2013 diatur dalam Permendikbud nomor 57 Tahun 2014. Dalam peraturan tersebut, salah satu formulasi pendidikan dasar adalah dengan menyelenggarakan pembelajaran tematik bagi sekolah dasar. Pembelajaran tematik ialah pembelajaran yang memadukan antara berbagai mata pelajaran atau bidang studi dengan menggunakan tema tertentu. Tujuannya adalah untuk memudahkan anak dalam memahami serta mengembangkan kemampuan sesuai dengan tema. Dengan menerapkan konsep tematik, diharapkan anak mampu mencapai hasil yang optimal dalam proses pemebelajaran. Pada tahap sekolah dasar, proses pembelajaran menjadi hal yang sangat fundamental. Hal ini dikarenakan dalam tahapan ini, anak akan mengenal serta memepelajari banyak hal baru di lingkungan yang baru. Oleh karena itu, diperlukan konsep, metode, serta strategi yang matang dalam menyukseskan pembelajaran formal di sekolah dasar.

Penelitian ilmiah yang berkaitan dengan penelitian ini ialah penelitian yang dilakukan oleh Karli (2010) dengan judul Penerapan Pembelajaran Tematik SD di Indonesia. Dalam penelitian tersebut, diungkapkan konsep, jenis, serta alasan pembelajaran tematik. Sari, dkk. (2018) yang meneliti Penerapan Pembelajaran Tematik Terpadu di Sekolah Dasar memiliki tujuan untuk mendekripsikan perencanaan, pelaksanaan, penilaian, hambatan, upaya, dan dampak pembelajara tematik terpadu SDN Purwosari 2 dan SDN Maranggen. Penelitian lain oleh 
Indriani (2015) ialah mengenai Kompetensi Pedagohik Mahasiswa dalam Mengelola Pembelajaran Tematik Intergratif Kurikulum 2013 pada Pengajaran Micro di PGSD UAD Yogyakarta. Arifin (2016) meneliti tentang Pengaruh Pembelajaran Tematik-Intergratif Berbasis Sosiokultural Terhadap Hasil Belajar Peserta Dikik Kelas III Sekolah Dasar. Selain itu, Pratiwi dan Arif Widagdo (2017) membuat penelitian mengenai Implementasi Pembelajaran Tematik pada Kelas Awal di Sekolah Dasar. Penelitian serupa lainya dilakukan oleh Ain dan Maris Kurniawati (2013) tentang Implementasi Kurikulum KTSP: Pembelajaran Tematik di Sekolah Dasar. Selanjutnya Amanda, dkk. (2019) meneliti Pengembangan Media Budel (Buku Berjendela) pada Tema Keluargaku. Gandasari (2019) juga meneliti Pengembangan Model Pembelajaran Jasmani Olahraga dan Kesehatan untuk Sekolah Dasar. Selain penelitian-penelitian tersebut, sebelumnya terdapat penelitian yang berkaitan dengan monitoring dan evaluasi dalam pembelajaran, seperti penelitian yang telah dilakukan oleh Fachrudidin (2014) yang meneliti Sistem Informasi Monitoring dan Evaluasi Perkuliahan (Stdi Kasus: STIKOM Dinamika Bangsa). Selain itu, Mariana (2017) menulis tentang Rancangan Sistem Evaluasi dan Monitoring Proses Pembelajaran Pada Program Studi. Gunawan, dkk. (2015) meneliti Implementasi Monitoring dan Evaluasi Proses Lesin Study di FKIP UM Surabaya.

Meskipun telah banyak dilakukan penelitian sebelumnya, penelitian ini akan mengkaji lebih spesifik pola materi kebahasaan, monitoring, serta evaluasi terhadap pembelajaran bahasa. Penelitian ini dilakukan karena bahasa adalah alat yang digunakan untuk mempelajari ilmu-ilmu yang lain. Oleh karena itu, rumusan masalah dalam penelitian ini dirumuskan sebagai berikut. 1) Bagaimana pola materi pembelajaran bahasa pada buku tematik sekolah dasar kelas 1? 2) Bagaimana monitoring dan evaluasi pembelajaran bahasa pada buku tematik sekolah dasar kelas 1? Dengan rumusan malasah tersebut, tujuan dari penelitian ini ialah 1) mendeskripsikan pola pembelajaran bahasa pada buku tematik sekolah dasar kelas 1 dan 2) mendeskripsikan bagaimana monitoring dan evaluasi pembelajaran bahasa pada buku tematik sekolah dasar kelas I.

\section{METODE}

Metode penelitian merupakan alat, prosedur dan teknik yang dipilih dalam melaksanakan penelitian (Djajasudarma 2010). Pada ranah kebahasaan, penelitian dapat dilakukan di lapangan dengan melibatkan peneliti dengan penutur. Selain itu, penelitian kebahasaan juga dapat dilakan secara kajian kepustakaan dengan melibatkan hubungan peneliti dengan buku sebagai sumber data. Dalam penelitian ini, metode pengumpulan data yang dilakukan adalah metode simak, yaitu menyimak pengunaan bahasa, baik lisan maupun tulisan (Mahsun, 2007). Teknik yang digunakan adalah teknik sadap sebagai teknik dasar, dan teknik catat sebagai teknik lanjutan dari metode simak. Data yang 
diambil bersumber dari Buku Tematik Terpadu Kurikulum 2013 Kelas 1 SD/MI. Dengan metode simak, penulis melakukan penyimakan pada setiap sub-tema yang terdapat dalam buku tematik terpadu kurikulum 2013 tersebut. Setelah itu, peneliti menyadap dan mencatat hal-hal yang berkaitan dengan kebahasaan. Penyajian hasil ananlisis data dilakukan dengan metode informal, yaitu penyajian dengan kata-kata dalam bentuk narasi.

\section{HASIL DAN PEMBAHASAN}

Sajian buku tematik bagi Sekolah Dasar memberikan warna baru bagi dunia literasi di bidang pendidikan dasar. Materi ajar yang terpadu menjadikan setiap mata pelajaran saling terintegrasi. Seperti dalam materi PPKN, di dalamnya tidak hanya terdapat aspek-aspek kewarganegaraan, tetapi juga aspek-aspek kebahasaan. Dalam mata pelajaran PPKN pada Buku Tematik Terpadu Kurikulum 2013 Buku Siswa SD/MI Kelas 1, peserta didik tidak hanya dituntut untuk memahami materi kewarganegaraan, tetapi secara perlahan juga terdapat aspek kebahasaan, seperti membaca teks atau yang lainnya. Hal ini merupakan contoh dari intergasi materi ajar yang ada dalam buku tersebut. Selain itu, untuk sistem monitoring dan evaluasi, Buku Tematik Terpau Kurikulum 2013 Buku Siswa SD/MI Kelas 1 menampilkan formulasi baru, yaitu "Sekarang Aku Bisa". Dengan sistem monitoring dan evaluasi tersebut, diharapkan capaian tiap indikator pembelajaran dapat teraih dengan baik. Untuk lebih jelasnya, bahasan selanjutnya merinci gagasan tersebut.

\section{Pola Materi Pembelajaran Bahasa}

Kurikulum yang digunakan dalam pembelajaran pada masa ini mengacu pada kurikulum 2013. Berdasarkan pada Permendikbud nomor 57 Tahun 2014, salah satu formulasi pendidikan dasar ialah dengan menyelenggarakan pembelajaran tematik bagi Sekolah Dasar. Dalam penelitian ini, objek yang digunakan adalah Buku Tematik Terpadu Kurikulum 2013 Buku Siswa SD/MI Kelas $I$.

Dalam buku siswa kelas I, terdapat 8 buku dengan 8 tema berbeda yang harus dipelajari pada satu tahun ajaran pendidikan yang dibagi dalam 2 semester. Tema-tema yang disajikan disesuaikan dengan kehidupan sehari-hari sehingga peserta didik pada tingkat dasar dapat mempelajari dengan mudah. Setiap tema terdapat sub-bab yang berkaitan dengan tema pada buku tersebut. Selain terdapat sub-bab, antara tema satu degan yang lain memiliki tingkatan yang berjenjang, mulai dari pembahasan dasar hingga pembahasan lanjut. Kedelapan tema tersebut adalah:

1. Tema 1: Diriku

2. Tema 2: Kegemaraku

3. Tema 3: Kegemaranku 
4. Tema 4: Keluargaku

5. Tema 5: Pengalamanku

6. Tema 6: Lingkungan Bersih, Sehat, dan Asri

7. Tema 7: Benda, Hewan, dan Tanaman di Sekitarku

8. Tema 8: Peristiwa Alam

Sesuai dengan Permendikbud nomor 57 tahun 2014, 8 tema tersebut terangkum dalam materi ajar berupa mata pelajaran: Bahasa Indonesia, PPKN, Matematika, Seni Budaya dan Prakarya, serta Pendidikan Jasmani Olahraga dan kesehatan. Untuk sekolah dasar kelas 1, alokasi waktu yang diperlukan perminggu ialah selama 30 jam pelajaran. Dari buku tematik tersebut, ditemukan bebebrapa aspek atau kompetensi pembelajaran secara umum yang meliputi: mengamati, mencoba, berlatih, bernyanyi, bercerita, berkreasi, menari, membaca, menulis, bermian peran, berdiskusi, dan berpikir.

Aspek-aspek tersebut merupakan kompetensi dasar yang harus dilakukan anak sebagai peserta didik dalam proses pembelajaran secara keseluruhan. Dalam pebelitian ini, para peneliti mengerucut pada penelitian pola kebahasaan yaitu: menyimak, membaca, menulis, serta berbicara. Kajian kebahasaan dalam buku tematik ini sangat luas. Hal ini dikarenakan dalam aspek berlatih, terkadang penyusun buku memasukkan bacaan atau teks untuk dibaca sehingga mengharuskan peserta didik membaca terselih daluhu sebelum berlatih.

Dalam buku pertama, tema 1: Diriku, terdapat 4 sub bab yang saling berkaitan yaitu; Aku dan Teman Baru, Tubuhku, Aku Merwat Tubuhku, dan Aku Istimewa. Untuk dapat memetakan pola materi kebahasaan, telah diperinci sebagai berikut.

Tabel 1. Tema 1

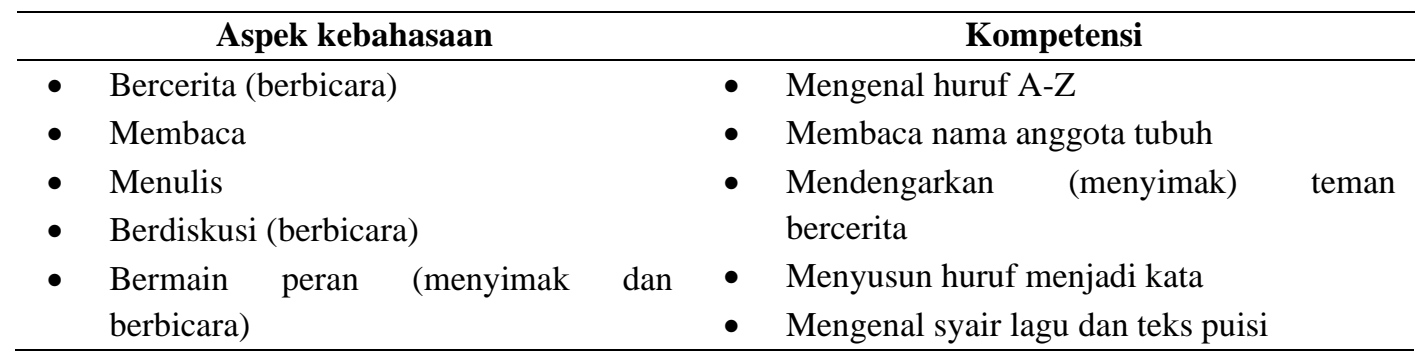

Pada tema 1, terdapat serangkaian aspek kebahasaan yang disajikan. Sementara itu, untuk kompetensi dasar seorang anak yang akan belajar, ilmu yang mulai dikenalkan adalah huruf A-Z, kemudian meningkat pada komepetensi berikutnya. Dalam Buku Tematik Terpadu Kurikulum 2013 Buku Siswa SD/MI Kelas 1 (2016) tema I sub-tema I, materinya mengajarkan peserta didik untuk mengenal huruf dengan cara bernyanyi. Secara tidak langsung, peserta didik memasuki ranah yang mendasar dari ilmu kebahasaan, yaitu fonologi. 
Dalam buku kedua, tema 2: Kegemaranku, terdapat 4 sub-bab yang saling berkaitan, yaitu: Gemar Berolah Raga, Gemar Bernyanyi dan Menari, Gemar Menggambar, serta Gemar Membaca. Untuk dapat memetakan pola materi kebahasaan, peneliti merinci isi mater tersebut sebagai berikut.

Tabel 2. Tema 2

\begin{tabular}{lll}
\hline \multicolumn{1}{c}{ Aspek kebahasaan } & \multicolumn{1}{c}{ Kompetensi } \\
\hline$\bullet$ Bercerita (berbicara) & $\bullet$ Menyimak cerita \\
- Membaca & $\bullet$ Bercerita \\
- Menulis & $\bullet$ Membaca suatu teks \\
- Berdiskusi (berbicara) & $\bullet$ Membaca puisi \\
- Bermain peran (menyimak dan & & \\
\hline & & \\
\hline
\end{tabular}

Pada buku ke 2 dalam tema 2, terdapat tingkatan pembelajaran bahasa, yaitu peserta didik dikenalkan dengan salah satu karya sastra berupa puisi. Proses ini diikuti oleh kompetensi kebahasaan yang lainnya. Dalam Buku Tematik Terpadu Kurikulum 2013 Buku Siswa SD/MI Kelas 1 (2016: 68-69) pada tema 2 sub tema 2, materinya mengajarkan peserta didik untuk mengenal puisi. Puisi yang dikenalkam ialah puisi yang berjudul Sahabat. Selain ilmu kebahasaan, pembahasan mengenai kesusastraan juga menjadi salah satu materi yang dikaji dalam buku ini.

Dalam buku ketiga, tema 3: Kegiatanku terdapat 4 sub bab yang saling berkaitan yaitu; Kegiatan Pagi Hari, Kegiatan Siang Hari, Kegiatan Sore Hari, dan Kegiatan Malam Hari. Untuk dapat memetakan pola materi kebahasaan, peneliti merinci matyeri tersebut sebagai berikut.

Tabel 3. Tema 3

\begin{tabular}{lll}
\hline \multicolumn{2}{c}{ Aspek kebahasaan } & \multicolumn{2}{c}{ Kompetensi } \\
\hline - Bercerita (berbicara) & - Mengenal kosa kata yang berhubungan \\
- Membaca & denga tema \\
- Menulis & - Menyusun huruf menjadi kata \\
- Berdiskusi (berbicara) & - Membaca huruf dan kata \\
- Bermain peran (menyimak dan & - Merangkai kata menjadi kalimat \\
& berbicara) & - Membuat cerita berdasarkan urutan gambar \\
& & - Menceritakan kembali \\
& & - Menulis pengalaman terkait tema \\
\hline
\end{tabular}

Pada buku ketiga, tema 3 terdapat peningkatan kompetensi bahasa. Jika pada tema 1 masih dikenalkan huruf, maka pada tema 3 sudah mulai dikenalkan kata dan kalimat kepada siswa. Selain itu, penunjang lain berupa gambar juga dapat digunakan sebagai media dalam pemeblajaran. Dalam Buku Tematik Terpadu Kurikulum 2013 Buku Siswa SD/MI Kelas 1 (2016: 84) pada tema 3 sub-tema 2 peserta didik DIA untuk melengkapi kalimat. Berdasarkan ilmu tentang 
kebahasaan atau linguistik, dalam fase ini, peserta didik memasuki ranah sintaksis.

Dalam buku keempat, tema 4: Keluargaku terdapat 4 sub-bab yang saling berkaitan, yaitu Anggota Keluargaku, Kegiatan Keluargaku, Keluarga Besarku, Kebersamaan dalam Keluarga. Untuk dapat memetakan pola materi kebahasaan, penulis merinci tema materi tersebut sebagai berikut.

Tabel 4. Tema 4

\begin{tabular}{|c|c|}
\hline Aspek kebahasaan & Kompetensi \\
\hline $\begin{array}{ll}\text { - } & \text { Bercerita (berbicara) } \\
\text { - } & \text { Membaca } \\
\text { - } & \text { Menulis } \\
\text { - } & \text { Berdiskusi (berbicara) } \\
\text { - } & \text { Bermain peran (menyimak dan } \\
& \text { berbicara) }\end{array}$ & $\begin{array}{ll}\text { - } & \text { Mejelaskan secara lisan dan tulisan terkait } \\
\text { - } & \text { Mema } \\
\text { - } & \text { Menjelaskan isi lagu } \\
\text { - } & \text { Berlatih (berbicara) untuk meminta izin } \\
\text { - } & \text { Menunjukkan ungkapan (berbicara) terima } \\
\text { kasih dan pujia }\end{array}$ \\
\hline
\end{tabular}

Pada buku keempat, tema 4 terdapat peningkatan kompetensi bahasa. Jika pada tema I masih dikenalkan huruf, maka pada tema 4 sudah mulai dikenalkan kata dan diaplikasikan dalam kalimat. Dalam Buku Tematik Terpau Kurikulum 2013 Buku Siswa SD/MI Kelas 1 (2016) pada tema 4 sub tema 4 materinya mengajarkan peserta didik untuk membuat kalimat dari kata-kata yang telah dipelajari. Berdasarkan ilmu tentang kebahasaan atau linguistik, dalam fase ini peserta didik memasuki ranah sintaksis.

Dalam buku kelima, tema 5: Pengalamanku, terdapat 4 sub-bab yang saling berkaitan, yaitu Pengalaman Masa Kecil, Pengalaman Bersama Teman, Pengalaman di Sekolah, dan Pengalaman yang Berkesan. Untuk dapat memetakan pola materi kebahasaan, maka penulis merinci materi sebagai berikut.

Tabel 5. Tema 5

\begin{tabular}{lll}
\hline \multicolumn{2}{c}{ Aspek kebahasaan } & \multicolumn{2}{c}{ Kompetensi } \\
\hline - Bercerita (berbicara) & - Mengungkapkan kalimat pujian \\
- Membaca & - Mengungkapkan kalimat permintaan maaf \\
- Menulis & - Mengungkapkan kata ajakan \\
- Berdiskusi (berbicara) & - Mengekspresikan puisi dan syair lagu \\
- Bermain peran (menyimak dan \\
$\quad$ berbicara)
\end{tabular}

Dalam tema 5, terdapat kenaikan kompetensi dari tema-tema sebelumnya. Pada tema 5 ini, peserta didik harus memiliki kompetensi untuk mengekspresikan puisi dan syair lagu. Jika sebelumnya hanya mengenal huruf dan membaca. Dalam Buku Tematik Terpadu Kurikulum 2013 Buku Siswa SD/MI 
Kelas 1 (2016) pada tema 5 sub tema 4, materinya mengajarkan peserta didik untuk mengekspresikan karya sastra dalam hal ini puisi.

Dalam buku keenam, tema 6: Lingkungan Bersih, Sehat, dan Asri, terdapat 4 sub-bab yang saling berkaitan, yaitu Lingkungan Rumahku, Lingkungan Sekitar Rumahku, Lingkungan Sekolahku, serta Bekerja Sama Menjaga Kebersihan dan Kesehatan Lingkungan. Untuk dapat memetakan pola materi kebahasaan, peneliti merinci materi tersebut sebagai berikut.

Tabel 6. Tema 6

\begin{tabular}{|c|c|}
\hline Aspek kebahasaan & Kompetensi \\
\hline - $\quad$ Bercerita (berbicara) & - $\quad$ Mengungkapkan petunjuk \\
\hline - $\quad$ Membaca & - Menanggapi ungkapan \\
\hline - Menulis & - Membuat ungkapan lisan dan tulisan \\
\hline - $\quad$ Berdiskusi (berbicara) & - $\quad$ Membuat kata ajakan \\
\hline $\begin{array}{l}\text { - } \begin{array}{l}\text { Bermain peran (menyimak dan } \\
\text { berbicara) }\end{array}\end{array}$ & - Membuat kalimat \\
\hline
\end{tabular}

Dalam tema 6 ini, selain membaca peserta didik diharapkan mampu untuk membuat sendiri ungkapan-ungkapan yang berkaitan dengan keseharian mereka, seperti; petunjuk, ajakan, serta pemberitahuan. Dalam Buku Tematik Terpadu Kurikulum 2013 Buku Siswa SD/MI Kelas 1 (2016) pada tema 6 sub tema 4, materinya mengajarkan peserta didik untuk membuat ungkapan dengan cara menyusun kata menjadi kalimat. Ranah kebahasaan yang ditujukan pada materi tersebut ialah pada ranah sintaksis.

Dalam buku ketujuh, tema 7: Benda, Hewan, dan Tanaman di Sekitarku terdapat 4 sub bab yang saling berkaitan, yaitu Benda Hidup dan Tak Hidup di Sekitar Kita, Hewan di Sekitarku, Tanaman di Sekitarku, Bentuk, Warna, Ukuran, dan Permukaan Benda. Untuk dapat memetakan pola materi kebahasaan, peneliti merinci materinya sebagai berikut.

Tabel 7. Tema 7

\begin{tabular}{|c|c|}
\hline Aspek kebahasaan & Kompetensi \\
\hline - $\quad$ Bercerita (berbicara) & - $\quad$ Menjelaskan kosa kata berdasarkan tema \\
\hline - Membaca & - Membuat kalimat berdasarkan tema \\
\hline - $\quad$ Menulis & - $\quad$ Menjelaskan suatu ungkapan \\
\hline - $\quad$ Berdiskusi (berbicara) & - Menulis suatu ungkapan \\
\hline $\begin{array}{l}\text { - } \begin{array}{l}\text { Bermain peran (menyimak dan } \\
\text { berbicara) }\end{array} \\
\text { nan }\end{array}$ & - Menggunakan suatu ungkapan \\
\hline
\end{tabular}

Pada tema ketujuh, terdapat kenaikan kompetensi, yaitu siswa mulai bisa mengaplikasikan kalimat yang mereka buat. Dalam Buku Tematik Terpadu Kurikulum 2013 Buku Siswa SD/MI Kelas 1 (2016) pada tema 7 sub tema 4 mengajarkan peserta didik untuk mengungkapkan kembali ungkapan yang telah dipelajari. Ungkapan yang dibuat kemudian dituangkan dalam suatu bentuk 
karangan. Aspek menulis yang hendak dicapai dituangkan dalam bentuk karangan. Dalam ilmu kebahasaan atau linguistik, ini termasuk dalam wacana.

Dalam buku kedelapan, tema 8: Peristiwa Alam terdapat 4 sub-bab yang saling berkaitan, yaitu Anggota Keluargaku, Kegiatan Keluargaku, Keluarga Besarku, dan Kebersamaan dalam Keluarga. Untuk dapat memetakan pola materi kebahasaan, peneliti merinci materi sebagai berikut.

Tabel 8. Tema 8

\begin{tabular}{lll}
\hline \multicolumn{2}{c}{ Aspek kebahasaan } & \multicolumn{1}{c}{ Kompetensi } \\
\hline - Bercerita (berbicara) & $\bullet$ & Mengenal kalimat terima kasih \\
- Membaca & - Mengucapkan terima kasih \\
- Menulis & - Menuliskalimat permintaan tolong \\
- Berdiskusi (berbicara) & - Menemukan kalimat permintaan tolong \\
- Bermain peran (menyimak dan & & dari teks bacaan \\
berbicara) & \\
\hline
\end{tabular}

Pada tema 8, terdapat tingkatan pada kompetensi bahasa. Peserta didik diharapkan mampu mengaplikasikan kompetensi dasar dalam kehidupan seharihari. Dalam Buku Tematik Terpadu Kurikulum 2013 Buku Siswa SD/MI Kelas 1 (2016) pada tema 8 sub tema 4 mengajarkan peserta didik untuk menceritakan kembali pengalaman dalam kehidupan sehari-hari secara bergantian. Aspek berbicara menjadi salah satu tolak ukur peserta didik memahami keseharian mereka dengan cara menceritakan kembali apa yang dialaminya.

Pada prinsipnya, pola kebahasaan yang terdapat dalam 8 tema tersebut saling berkesinambungan dan sistematis. Cakupan ranah kebahasaan dari satuan terkecil yang berupa fonem hingga wacana terangkum dalam satu paket buku tematik terpadu kurikulum 2013. Selain itu, aspek kebahasaan, seperti membaca, menulis, menyimak, berbicara serta kompetensi dasar bahasa hingga pada pengaplikasiannya banyak sekali ditemukan dalam buku tersebut. Dalam buku tematik tersebut juga terdapat kompetensi penunjang yang berupa penulisan huruf tegak bersambung, seperti yang ada dalam kurikulum sebelumsebelumnya. Hal ini berimplikasi bahwa dengan model tematik yang sistematis, yaitu peserta didik dapat lebih mudah dalam mempelajari sesuatu secara holistik. Hal ini dikarenakan urutan proses belajar yang bertingkat, serta sesuai dengan kehidupan sehari-hari. Peserta didik yang dalam rentang usia perkembangan semacam ini dapat merekam proses belajar dan menangkap apa yang mereka pelajari dengan cukup dalam.

\section{Monitoring dan Evaluasi Kebahasaan}

Dalam pembelajaran, proses monitoring dan evaluasi tidak dapat dihilangkan karena hal tersebut menjadi salah satu komponen penyusun pembelajaran. Selain itu, untuk mengetahui tingkat keberhasilan atau pencapaian pembelajaran, salah satu yang menjadi komponen dalam monitoring dan evaluasi 
adalah penialian. Penilaian dapat dilakukan pada beberapa hal, seperti kognitif, afektif, serta psikomotorik. Dalam penilaian kognitif, peserta didik diukur seberapa jauh pemahaman terhdap pengetahuan yang mereka dapatkan. Untuk dapat mengetahi pencapaian kognitif, maka bisa dilakukan dengan penilaian tugas yang berkaitan dengan wawasan atau pengetahuan. Sesuai dengan permendikbud maka persentase beban belajar penugasan terstruktur dan kegiatan mandiri maksimal adalah $40 \%$ dari waktu kegiatan tatap muka mata pelajaran yang terkait. Oleh karena itu, anak sebagai peserta didik tidak terlalu dibebankan dengan penugasan. Dalam penilaian afektif, peserta didik dapat dinilai dari segi sikap ketika berinteraksi di lingkungan sekolah. Selain itu, aspek psikomotorik dapat juga dinilai dari kecakapan dalam berinteraksi.

Dalam administrasi pembelajaran, guru diharapkann mampu menggunakan alat monitoring dan evaluasi guna mengetahui persentase keberhasilan pembelajaran. Dalam buku Tematik Terpadu Kurikulum 2013 Buku Siswa SD/MI Kelas 1, terdapat formulasi baru yang bisa digunakan untuk monitoring sekaligus evaluasi pembelajaran. Dalam buku, beberapa halaman dibiarkan kosong. Hal ini difungsikan untuk kegiatan siswa yang berhubugan dengan keterampilan praktik yang mencakup penilaian psikomotorik.

Yang menjadi formulasi lainya adalah pada setiap akhir sub-bab, terdapat satu lembar yang difungsikan sebagai alat evaluasi untuk mengukur ketercapaian pembelajaran. Penyusun Buku Tematik Terpadu Kurikulum 2013 Buku Siswa SD/MI Kelas 1 memberi nama alat evaluasi ini dengan nama "Sekarang Aku Bisa”. Dengan memberikan tanda centang $(\sqrt{ })$ pada poin-poin yang sudah tercapai maka dari situlah kita dapat mengetahui ketercapaian pembelajaran setiap peserta didik secara komperhensif dan nyata.

\section{SIMPULAN}

Secara umum, terdapat formulasi baru yang disajikan dalam buku Tematik Terpadu Kurikulum 2013 Buku Siswa SD/MI Kelas 1. Dilihat dari polanya, aspek dan kompetensi kebahasaan dipelajari oleh siswa secara sistematis, mulai dari mengenal huruf A-Z, kata, kalimat, hingga pada teks atau wacana. Selain itu, aspek kebahasaan yang dipelajari juga cukup komperhensif karena mencakup aspek menyimak, membaca, menulis, dan berbicara. Melalui buku Tematik Terpadu Kurikulum 2013 Buku Siswa SD/MI Kelas 1, peserta didik diarahkan untuk bisa memenuhi setiap aspek dengan kompetensi yang tersusun secara sistematis. Pembelajaran secara tematik memiliki keunggulan, yaitu dapat mempermudah siswa dalam mempelajari sesuatu secara holistik. Hal ini karena metode tersebut berkaitan dengan kehidupan sehari-hari. Kemudian untuk dapat mengetahui keberhasilan pencapaian, diperlukan juga monitoring dan evaluasi dalam setiap pembelajaran. Dalam buku tersebut, terdapat lembaran khusus yang berfungsi sebagai lembar latihan. Dalam hal ini lembaran yang dimaksud adalah monitoring serta lembar evaluasi dengan nama "Sekarang Aku Bisa". 


\section{DAFTAR PUSTAKA}

Ain, Nurul dan Maris Kurniawati. 2013. "Implementasi Kurikulum KTSP: Pembelajaran Tematik di Sekolah Dasar". Jurnal Inspirasi Pendidikan Universitas Kanjuruhan Malang.Vol 3. No. 2. 316-328. DOI: https://doi.org/10.21067/jip.v3i2.373.

Amanda, Niken, dkk. 2019. "Pengembangan Media Budel (Buku Berjendela) pada Tema Keluargaku". Jurnal Penelitian dan Pengembangan $\begin{array}{lllll}\text { Pendidikan. } & \text { Vol. } & 3 & \text { No. } & \text { 2: }\end{array}$ DOI: http://dx.doi.org/10.23887/jppp.v3i2.17384.

Arifin, Slamet. 2016. "Pengaruh Pembelajaran Tematik-Integratif Berbasis Sosiokultural terhadap Hasil Belajar Peserta Didik Kelas III Sekolah Dasar". Profesi Pendidikan Dasar. Vol. 3 No. 1: 19-29.

Djajasudarma, Fatimah. 2010. Metode Linguistik: Ancangan Metode Penelitian dan Kajian. Bandung: Reflika Aditama.

Fachruddin. 2014. "Sistem Informasi Monitoring dan Evaluasi Perkuliahan (Studi Kasus: Stikom Dinamika Bangsa)”. Jurnal Ilmiah Media SISFO. Vol.8 No.3: 57-76.

Gandasari, Maharani Fatima. 2019. "Pengembangan Model Pembelajaran Tematik Pendidikan Jasmani Olahraga dan Kesehatan Untuk Sekolah Dasar". Jurnal Pendidikan Jasmani Indonesia. Vol. 15 No. 1: 22-27. DOI: https://doi.org/10.21831/jpji.v15i1.25489.

Gunawan, dkk. 2015. "Implementasi Monitoring dan Evaluasi Proses Lesson Study Di FKIP UM Surabaya". Didaktis. Vol. 15 No. 1: 1 - 116. DOI: http://dx.doi.org/10.30651/didaktis.v15i3.73.

Indriani, Fitri. 2015. "Kompetensi Pedagogik Mahasiswa dalam Mengelola Pembelajaran Tematik Integratif Kurikulum 2013 Pada Pengajaran Micro di PGSD UAD Yogyakarta”. Profesi Pendidikan Dasar. Vol. 2 No. 2: 87 94.

Karli, Hilda. 2010. "Penerapan Pembelajaran Tematik SD di Indonesia". Jurnal $\begin{array}{llllll}\text { EduHumaniora. } & \text { Vol. } & 2 & \text { No. } & 1 \text { : } & 1-11 .\end{array}$

DOI: https://doi.org/10.17509/eh.v2i1.2752.

Kemendikbud. 2017. Diriku. Jakarta: Kemendikbud.

Kemendikbud. 2017. Kegemaranku Jakarta: Kemendikbud.

Kemendikbud. 2017. Kegiatanku. Jakarta: Kemendikbud.

Kemendikbud. 2017. Keluargaku. Jakarta: Kemendikbud.

Kemendikbud. 2017. Pengalamanku Jakarta: Kemendikbud.

Kemendikbud. 2017. Lingkungan Bersih, Sehat, dan Asri. Jakarta: Kemendikbud.

Kemendikbud. 2017. Benda, Hewan, dan Tanaman di Sekitarku. Jakarta: Kemendikbud.

Kemedikbud. 2017. Peristiwa Alam. Jakarta: Kemendikbud.

Mahsun. 2007. Metode Penelitian Bahasa. Jakarta: PT. Gramedia Pustaka Utama.

Permendikbud. 2014. Lampiran Permendikbud Nomor 57 Tahun 2014.

Mariana, dkk. 2017. "Rancangan Sistem Evaluasi dan Monitoringproses Pembelajaran pada Program Studi”. Prosiding SINTAK. 365-371. 
Pratiwi, Rokhimah Kusuma dan Arif Widagdo. 2017. "Implementasi Pembelajran Tematik pada Kelas Awal di Sekolah Dasar”. Joyful Learning Journal. Vol. 6 No. 4: 277-284.

Sari, Novika Auliyana, dkk. 2018. "Penerapan Pembelajaran Tematik Terpadu di Sekolah Dasar". Jurnal Pendidikan: Teori, Penelitian, dan Pengembangan. Vol. 3 No. 12: 1572-1582. DOI: 10.1797/jptpp.v3i12.11796.

Sukmadinata, Nana Syaodih. 2009. Landasan Psikologi Proses Pendidikan. Bandung: PT Remaja Rosdakarya. 